\title{
‡USGS
}

science for a changing world

\section{Thermal and Hydrological Observations near Twelvemile Lake in Discontinuous Permafrost, Yukon Flats, Interior Alaska, September 2010-August 2011}

By Steven M. Jepsen, Joshua C. Koch, Joshua R. Rose, Clifford I. Voss, and Michelle A. Walvoord

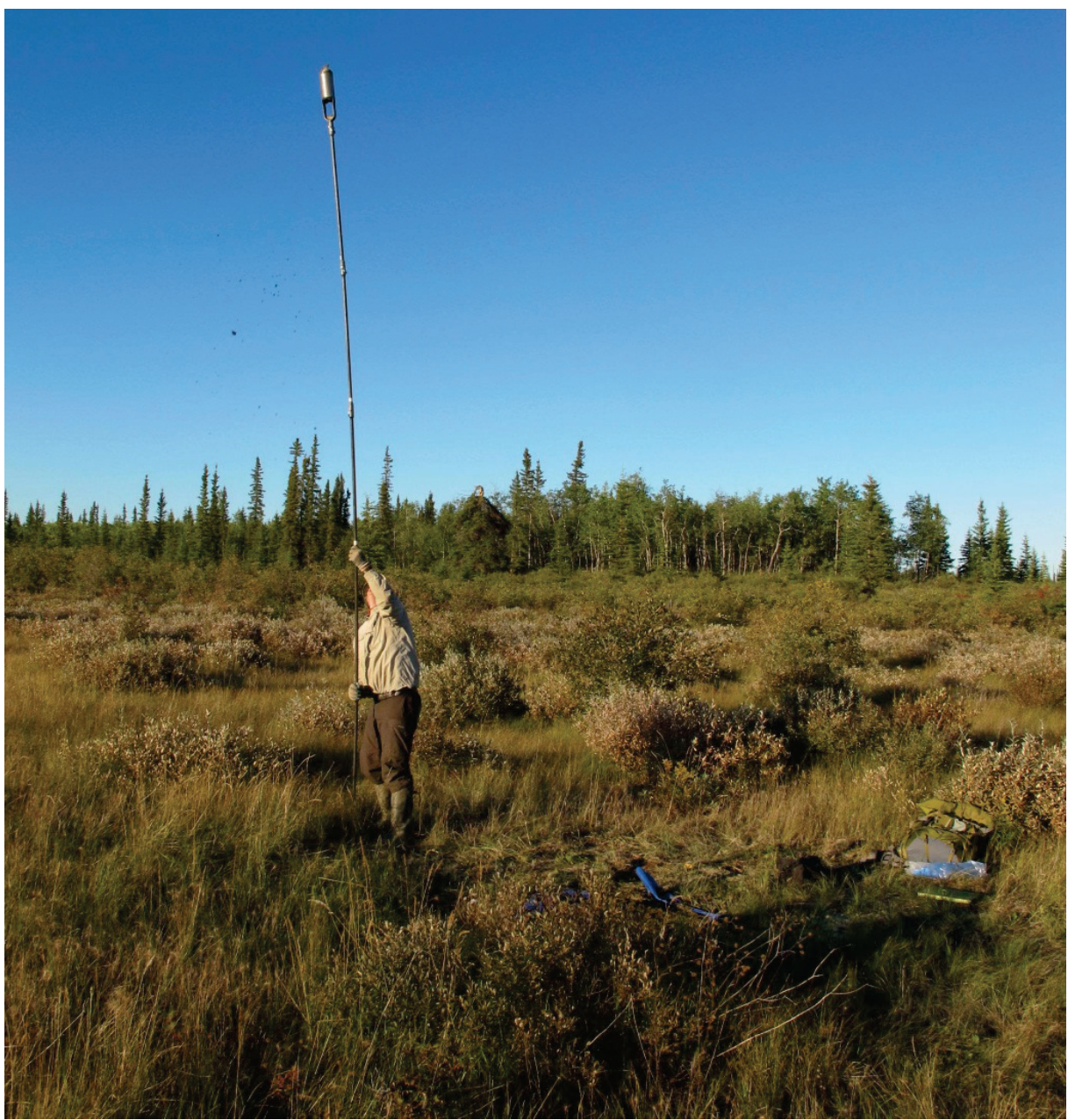

Open-File Report 2012-1121

U.S. Department of the Interior

U.S. Geological Survey 


\section{U.S. Department of the Interior \\ KEN SALAZAR, Secretary}

\section{U.S. Geological Survey \\ Marcia K. McNutt, Director}

U.S. Geological Survey, Reston, Virginia: 2012

For more information on the USGS-the Federal source for science about the Earth, its natural and living resources, natural hazards, and the environment-visit http://www.usgs.gov or call 1-888-ASK-USGS

For an overview of USGS information products, including maps, imagery, and publications, visit $h$ ttp://www.usgs.gov/pubprod

To order this and other USGS information products, visit $h$ ttp://store.usgs.gov

Suggested citation:

Jepsen, S.M., Koch, J.C., Rose, J.R., Voss, C.I., and Walvoord, M.A., 2012, Thermal and hydrological observations near Twelvemile Lake in discontinuous permafrost, Yukon Flats, interior Alaska, September 2010-August 2011 : U.S. Geological Survey Open-File Report 2012-1121, 25 p.

Any use of trade, product, or firm names is for descriptive purposes only and does not imply endorsement by the U.S. Government.

Although this report is in the public domain, permission must be secured from the individual copyright owners to reproduce any copyrighted material contained within this report. 


\section{Contents}

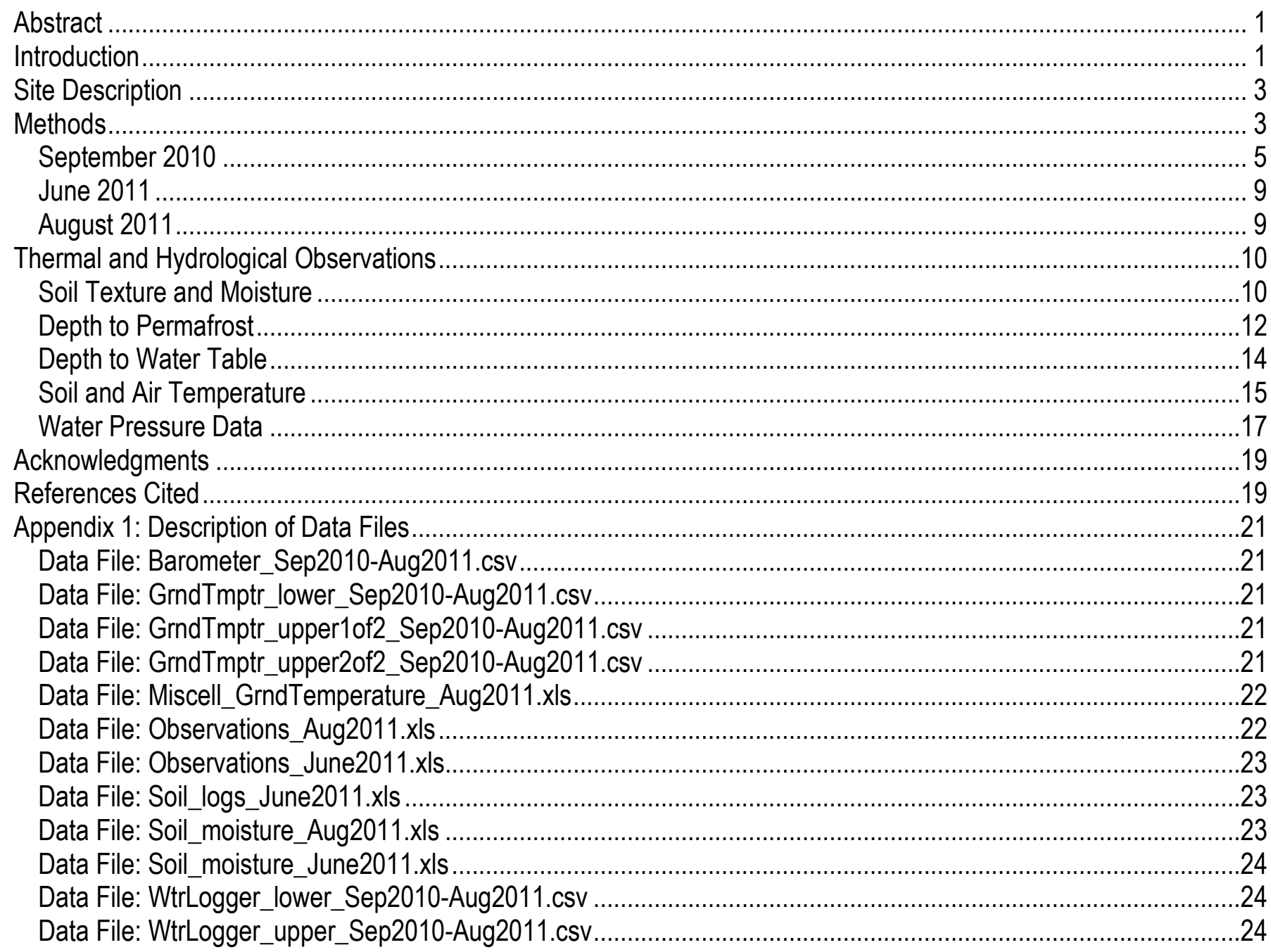

\section{Figures}

Figure 1. Location map of study area with LIDAR 2.5-meter-resolution topography and surface features visible from satellite .......

Figure 2. Site locations and plot identification numbers for the fieldwork periods September 28-30, 2010, and June $18-24,2011$......

Figure 3. Installation of temperature and water level loggers at the upper spruce site and the lower deciduous site near Twelvemile Lake, September 29, 2010

Figure 4. Photos of instruments used to record subsurface temperature and water pressure ............................. 8

Figure 5. Site locations and plot identification numbers for the fieldwork period August 19-27, 2011 .................. 10

Figure 6. Depth to permafrost as a function of liquid water content at sites where soil moisture was measured and digging was rejected by ice for the fieldwork period August 19-27, 2011.

Figure 7. Maximum observation depths in areas of ground ice (estimated depth to permafrost) and no ground ice,

Twelvemile and Buddy Lake watersheds, Alaska, during September 2010 and August $2011 .$.

Figure 8. Water-table elevations observed in the inlet and outlet channels of Twelvemile Lake, as a function of distance from the 2010 lake boundary. 
Figure 9. Ground and air temperatures observed near Twelvemile Lake at the upper spruce site and the lower deciduous site...

Figure 10. Water pressures observed 11 centimeters above the permafrost table at the upper spruce site and 14 centimeters above the permafrost table at the lower deciduous site during April-August 2011

\section{Tables}

Table 1. Permafrost observations and locations of dataloggers installed near Twelvemile Lake, Yukon Flats, Alaska, during the fieldwork period of September 28-30, 2010

Table 2. Laboratory-measured, grain-size mass fractions of soil samples collected from Twelvemile Lake and Buddy Lake watersheds, Alaska, during the June 18-24, 2011 fieldwork

Table 3. Seasonal averages in observed ground temperature at the upper spruce site, the lower deciduous site, and barometer near Twelvemile Lake between October 01, 2010, and August 19, 2011 


\title{
Thermal and Hydrological Observations near Twelvemile Lake in Discontinuous Permafrost, Yukon Flats, Interior Alaska, September 2010-August 2011
}

By Steven M. Jepsen, Joshua C. Koch, Joshua R. Rose, Clifford I. Voss, and Michelle A. Walvoord

\begin{abstract}
A series of ground-based observations were made between September 2010 and August 2011 near Twelvemile Lake, 19 kilometers southwest of Fort Yukon, Alaska, for use in ongoing hydrological analyses of watersheds in this region of discontinuous permafrost. Measurements include depth to ground ice, depth to water table, soil texture, soil moisture, soil temperature, and water pressure above the permafrost table. In the drained basin of subsiding Twelvemile Lake, we generally find an absence of newly formed permafrost and an undetectable slope of the water table; however, a sloping water table was observed in the low-lying channels extending into and away from the lake watershed. Datasets for these observations are summarized in this report and can be accessed by clicking on the links in each section or from the Downloads folder of the report Web page.
\end{abstract}

\section{Introduction}

A series of ground-based measurements were made near Twelvemile Lake in the Yukon Flats of interior Alaska between September 2010 and August 2011 to provide data for use in ongoing hydrological analyses of watersheds in this region of discontinuous permafrost. Twelvemile Lake is an area of focused interest because of its approximate 4-meter $(\mathrm{m})$ decline in surface elevation since the 1950s (M.T. Jorgenson, Alaska Ecoscience, oral commun., 2011). The study area includes the Twelvemile Lake watershed, located about 19 kilometers $(\mathrm{km})$ southwest of Fort Yukon, and the "Buddy Lake" watershed, located about $2 \mathrm{~km}$ southeast of Twelvemile Lake (fig. 1). The following measurements were made and are presented in this report: depth to ground ice, depth to water table, soil texture, soil moisture, soil temperature, and water pressure above the permafrost table. The latter two parameters were recorded continuously at two sites. 


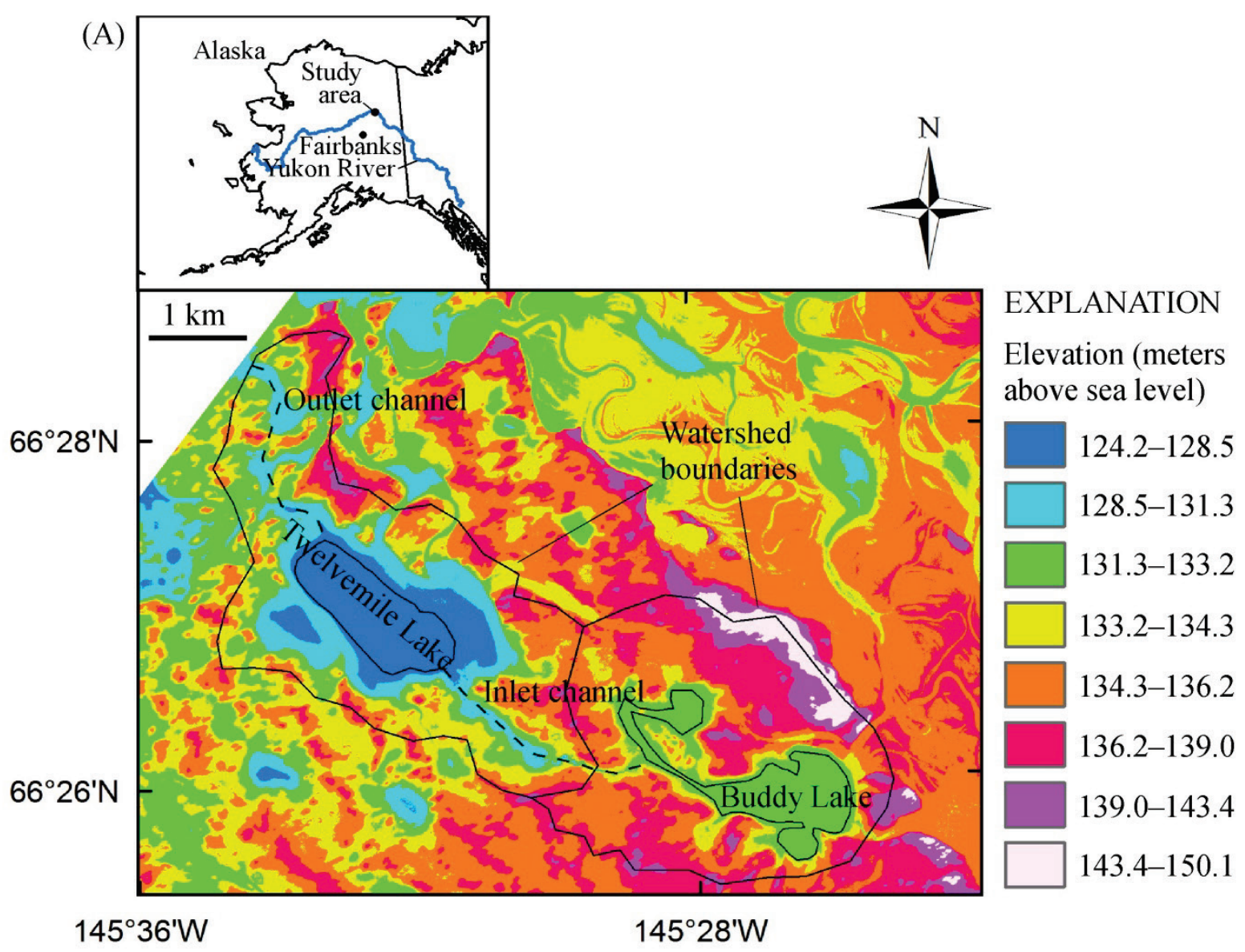

(B)

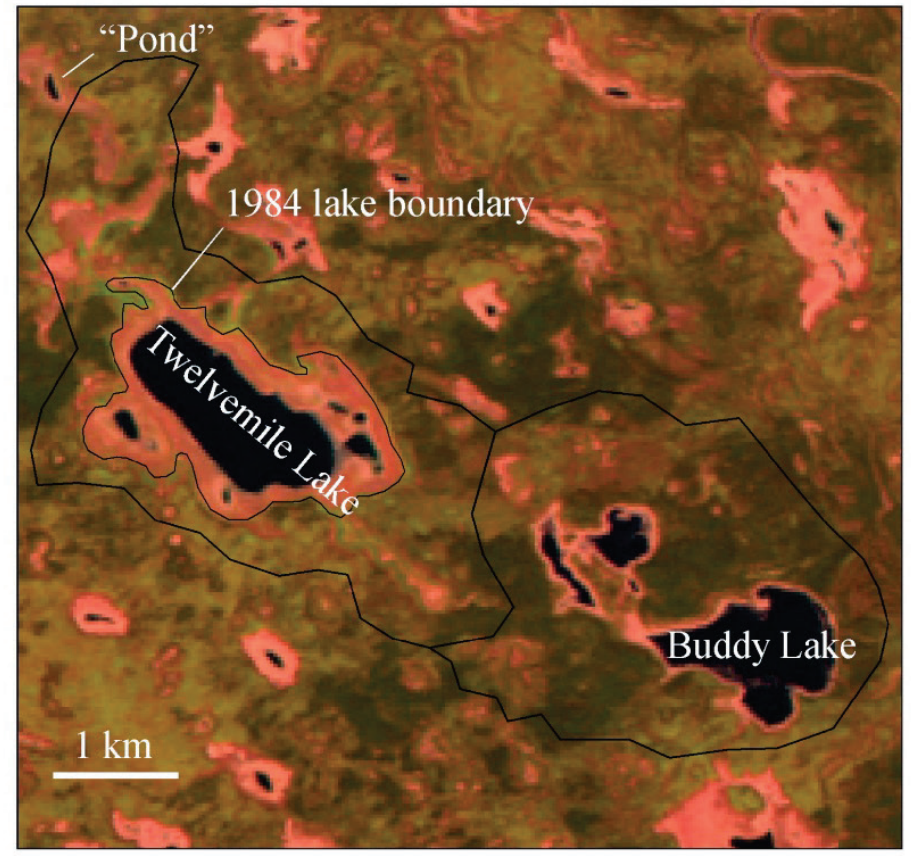

EXPLANATION

Land cover type (approximate)

Meadow or bare soil

Deciduous forest

Spruce forest

Water

Figure 1. Location map of study area with (A) LIDAR 2.5-meter-resolution topography (Gesch, 2007) and (B) surface features visible from satellite (taken by Landsat 5 , May 28, 2011). Lake boundaries were traced from Landsat images taken in 1984 and 2010. (LIDAR, light detection and ranging) 


\section{Site Description}

The sediment of the study area generally consists of silt and fine sand to a depth of up to about 4 m (observed in this study; M.T. Jorgenson, Alaska Ecoscience, oral commun., 2011) underlain by fluvial gravel, which appears to represent deposits of the Yukon River alluvial fan (Williams, 1962). Vegetation in the Twelvemile Lake watershed follows a successional sequence (Chapin and others, 2006) of sedge and grass meadows in the low-lying areas most recently submerged under water, grading upward in elevation into deciduous forests of willow, balsam poplar, aspen, and birch near the early1980s lake margin, and grading finally into the oldest perennial forests of white spruce (fig. $1 B$ ). A surface mantle of terrestrial organic soil ranges in thickness from less than 10 centimeters $(\mathrm{cm})$ in the white spruce, where it is predominantly fibric (moss), to thicker sequences (reaching $50 \mathrm{~cm}$ ) of hemic and sapric organics in the low-lying channel features near and outside of the early-1980s margin of Twelvemile Lake. Williams (1962) and Nakanishi and Dorava (1994) provide summaries of vegetation, climate, hydrology, and geology near Fort Yukon.

\section{Methods}

Data were collected during three site visits taking place during September 2010, June 2011, and August 2011. Transportation was provided by a floatplane from Fairbanks to the northeastern boundary of Twelvemile Lake, where camp was established (fig. 2B, Plot identification [ID] 31). Observed depths to permafrost are herein defined as the depth where deeper digging or frost probing into frozen sediment is not possible during the late summer and early fall fieldwork (September 2010 and August 2011). This observation is referred to as "auger rejection by ice." 

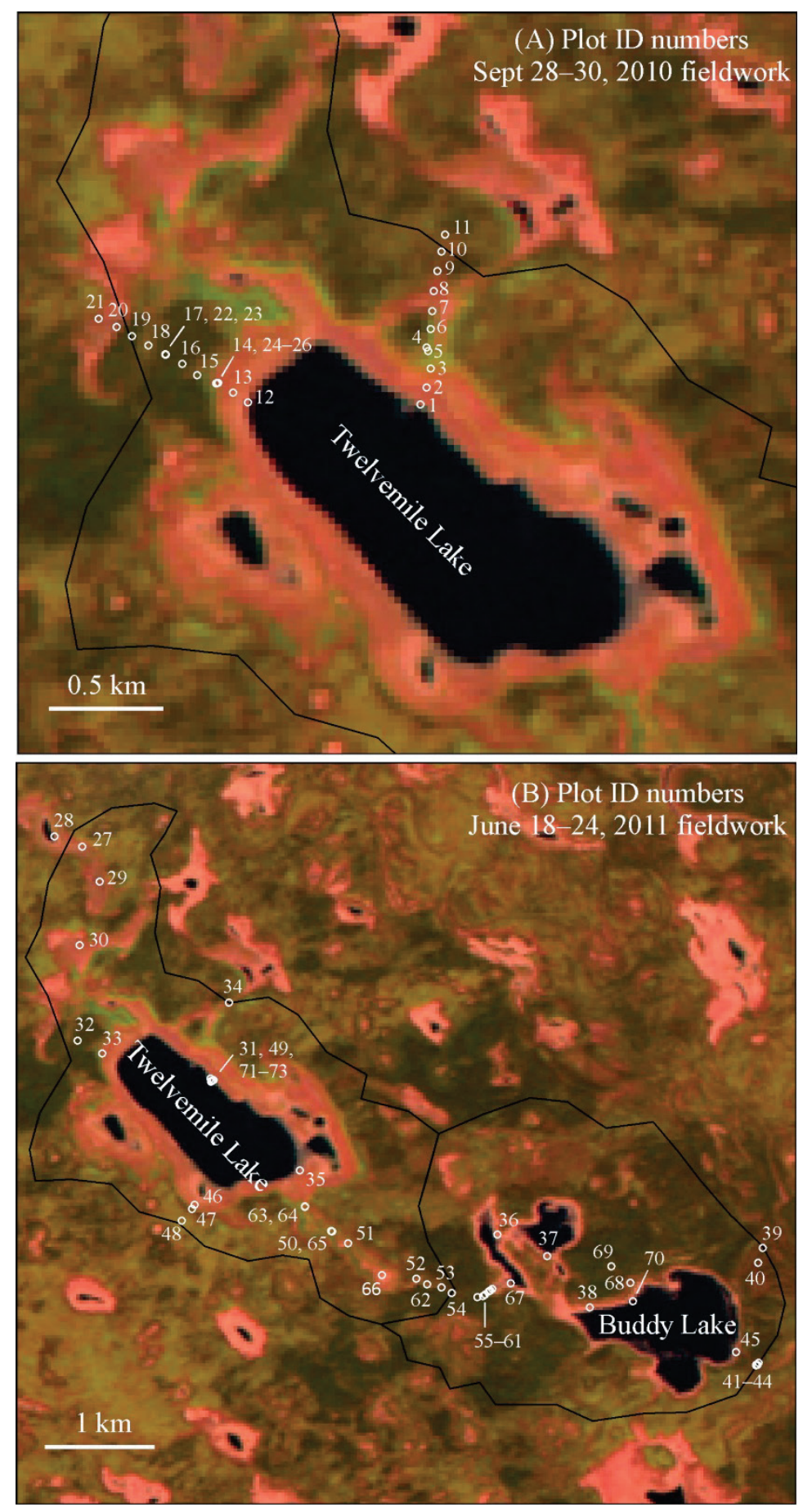

Figure 2. Site locations and plot identification (ID) numbers for the fieldwork periods (A) September 28-30, 2010, and $(B)$ June 18-24, 2011 (see fig. 5 for locations of August 2011 sites). Plot ID numbers are referenced in the data files. They are different from "site names," also referenced in the data files. (Base image taken by Landsat 5, May 28, 2011.) 
Vegetation type of the sites visited is classified into one of the following categories: meadow, consisting of grasses and sedges with minor shrubs (including willow); shrubland, consisting of shrubs (primarily willow); deciduous forest, consisting primarily of balsam poplar, aspen, birch, and willow; and spruce forest, consisting primarily of white spruce and often with a groundcover of moss.

To assess the spatial pattern of depth-to-permafrost over areas not physically accessed, permafrost observations are superposed over a grid of electrical ground resistivity (upper $10 \mathrm{~m}$, thickness-weighted average of six geophysical inversion layers) obtained from a geophysical inversion of data from an airborne electromagnetic survey (Minsley and others, 2012; Abraham, 2011; Ball and others, 2011). Electrical resistivity of the ground generally increases with ice content because of the high resistivity of ice relative to other soil constituents, thus providing a proxy for depth to permafrost. All recorded depths are relative to the top of the soil profile (including organic material if any), unless noted otherwise. The methods and data collected during each of the three site visits are described below.

\section{September 2010}

Fieldwork was conducted during the period of September 28-30, 2010, to measure depth to permafrost by frost probing and to install two temperature monitoring stations in the suprapermafrost soil column and two water-level loggers near the permafrost table (site locations shown in figs. $2 A$ and 3 ; table 1). Four frost-probe extensions were carried in the field to provide a maximum depth of observation of $4.8 \mathrm{~m}$. The spacing between frost probe measurements was planned in the field based on depth to permafrost, as inferred from apparent resistivity maps (140 kilohertz) from an airborne electromagnetic survey (Abraham, 2011; Ball and others, 2011; Minsley and others, 2012), and the expected number of points that could be collected in one day.

On September 29, 2010, temperature dataloggers and water-level loggers were installed at an upper spruce site (fig. $2 A$, Plot IDs 22, 23; fig. $3 A$; table 1 ) and a lower deciduous site (fig. $2 A$, Plot IDs 24, 25; fig. $3 B$; table 1$)$. 
Table 1. Permafrost observations and locations of dataloggers installed near Twelvemile Lake, Yukon Flats, Alaska, during the fieldwork period of September 28-30, 2010. Site locations are plotted in figure $2 A$.

[ID, identification; deg, degree; m, meter; m/dd/yyyy, month/day/year; n/a, not applicable. Permafrost-yes, top of permafrost found at depth of maximum penetration; no, permafrost not found. Reference datum for coordinates is WGS1984]

\begin{tabular}{|c|c|c|c|c|c|c|}
\hline $\begin{array}{l}\text { Plot } \\
\text { ID }\end{array}$ & $\begin{array}{l}\text { Longitude } \\
\text { (deg) }\end{array}$ & $\begin{array}{l}\text { Latitude } \\
\text { (deg) }\end{array}$ & $\begin{array}{l}\text { Maximum } \\
\text { penetration } \\
(\mathrm{m})\end{array}$ & Description & $\begin{array}{c}\text { Date } \\
\text { (m/dd/yyyy) }\end{array}$ & $\begin{array}{l}\text { Permafrost at depth } \\
\text { of maximum } \\
\text { penetration? }\end{array}$ \\
\hline 1 & -145.543722 & 66.454419 & 4.59 & Frost probe observation & $9 / 28 / 2010$ & No \\
\hline 2 & -145.543020 & 66.455111 & 2.86 & Frost probe observation & $9 / 28 / 2010$ & No \\
\hline 3 & -145.542578 & 66.455887 & 2.15 & Frost probe observation & $9 / 28 / 2010$ & No \\
\hline 4 & -145.542943 & 66.456736 & 3.02 & Frost probe observation & $9 / 28 / 2010$ & Yes \\
\hline 5 & -145.542807 & 66.456595 & 0.00 & Frost probe observation & $9 / 28 / 2010$ & No \\
\hline 6 & -145.542485 & 66.457493 & 1.77 & Frost probe observation & $9 / 28 / 2010$ & Yes \\
\hline 7 & -145.542268 & 66.458220 & 0.62 & Frost probe observation & $9 / 28 / 2010$ & Yes \\
\hline 8 & -145.542053 & 66.459041 & 1.79 & Frost probe observation & $9 / 28 / 2010$ & Yes \\
\hline 9 & -145.541660 & 66.459845 & 1.06 & Frost probe observation & $9 / 28 / 2010$ & Yes \\
\hline 10 & -145.541170 & 66.460628 & 0.80 & Frost probe observation & $9 / 28 / 2010$ & Yes \\
\hline 11 & -145.540808 & 66.461328 & 0.76 & Frost probe observation & $9 / 28 / 2010$ & Yes \\
\hline 12 & -145.561275 & 66.454665 & 3.09 & Frost probe observation & $9 / 28 / 2010$ & No \\
\hline 13 & -145.562777 & 66.455089 & 3.40 & Frost probe observation & $9 / 28 / 2010$ & No \\
\hline 14 & -145.564483 & 66.455476 & 1.20 & Frost probe observation & $9 / 28 / 2010$ & Yes \\
\hline 15 & -145.566402 & 66.455836 & 0.94 & Frost probe observation & $9 / 28 / 2010$ & Yes \\
\hline 16 & -145.567865 & 66.456306 & 1.16 & Frost probe observation & $9 / 28 / 2010$ & Yes \\
\hline 17 & -145.569510 & 66.456690 & 0.97 & Frost probe observation & $9 / 28 / 2010$ & Yes \\
\hline 18 & -145.571282 & 66.457084 & 0.39 & Frost probe observation & $9 / 28 / 2010$ & Yes \\
\hline 19 & -145.572921 & 66.457474 & 0.36 & Frost probe observation & $9 / 28 / 2010$ & Yes \\
\hline 20 & -145.574504 & 66.457863 & 0.71 & Frost probe observation & $9 / 28 / 2010$ & Yes \\
\hline 21 & -145.576301 & 66.458219 & 0.95 & Frost probe observation & $9 / 28 / 2010$ & Yes \\
\hline 22 & -145.569570 & 66.456689 & $\mathrm{n} / \mathrm{a}$ & Upper temperature dataloggers & $9 / 29 / 2010$ & $\mathrm{n} / \mathrm{a}$ \\
\hline 23 & -145.569552 & 66.456716 & $\mathrm{n} / \mathrm{a}$ & Upper water-level logger & $9 / 29 / 2010$ & $\mathrm{n} / \mathrm{a}$ \\
\hline 24 & -145.564412 & 66.455482 & $\mathrm{n} / \mathrm{a}$ & Lower temperature dataloggers & $9 / 29 / 2010$ & $\mathrm{n} / \mathrm{a}$ \\
\hline 25 & -145.564367 & 66.455493 & $\mathrm{n} / \mathrm{a}$ & Lower water-level logger & $9 / 29 / 2010$ & $\mathrm{n} / \mathrm{a}$ \\
\hline 26 & -145.564238 & 66.455486 & $\mathrm{n} / \mathrm{a}$ & Barometer/air temperature & 9/30/2010 & $\mathrm{n} / \mathrm{a}$ \\
\hline
\end{tabular}


(B) Lower deciduous site

(A) Upper spruce site
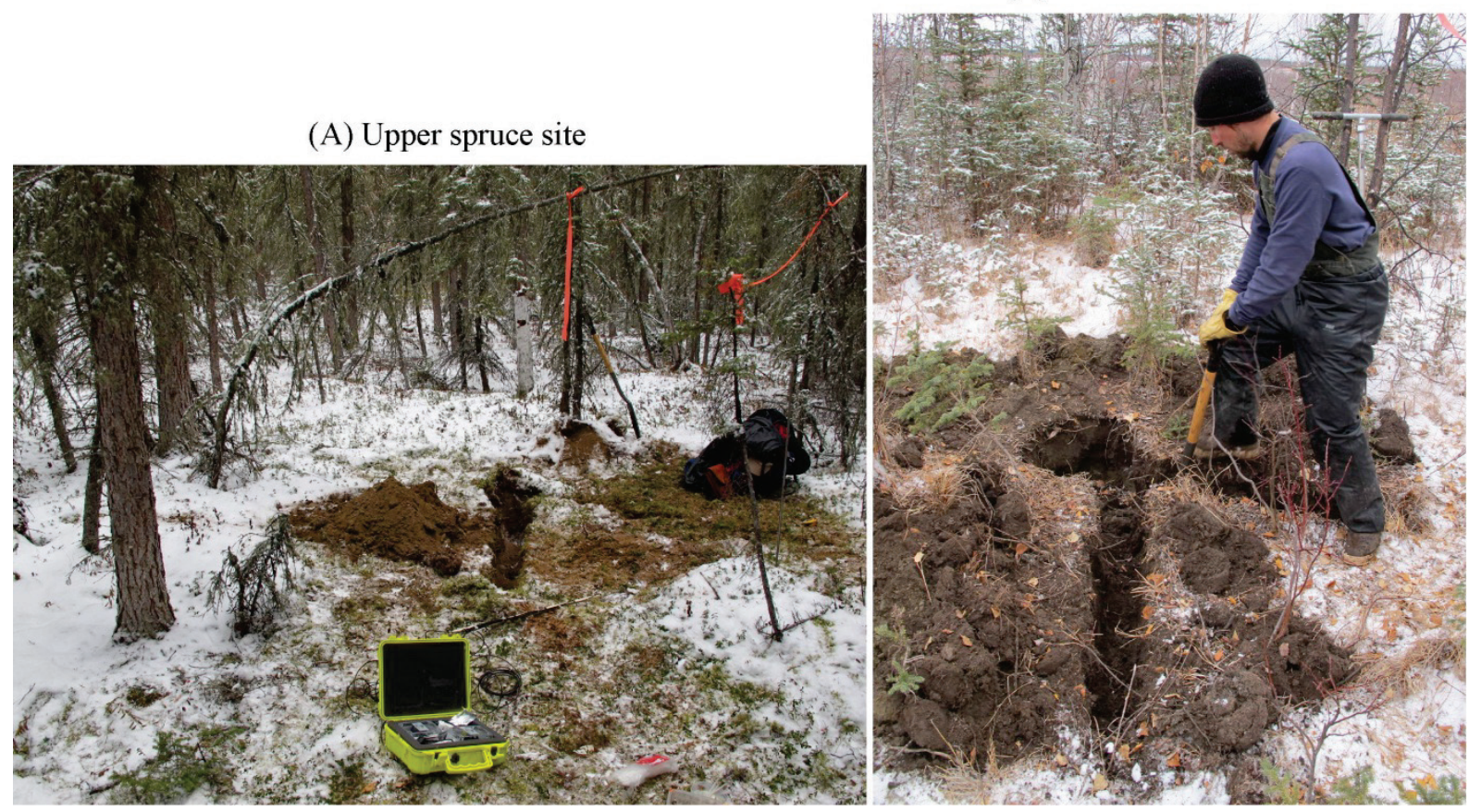

Figure 3. Installation of temperature and water level loggers at $(A)$ the upper spruce site and $(B)$ the lower deciduous site near Twelvemile Lake, September 29, 2010. The plot identification numbers for the temperature and water level loggers are 22 and 23 at the upper site and 24 and 25 at the lower site, respectively. Site locations are plotted in figure $2 A$.

The upper spruce site was populated by an open forest (approximately 20 percent canopy cover) of white spruce (fig. $3 A$ ). The mineral soil was generally covered by a layer of feather moss approximately $7 \mathrm{~cm}$ thick (for soil description, see Plot ID 32 in data files "Soil_logs_June2011.xls" and "Observations_June2011.xls"). The lower deciduous site (fig. 3B) was also in an open forest populated by birch and small spruce trees. It did not have a groundcover of moss (for soil description, see Plot ID 33 in data files "Soil_logs_June2011.xls" and "Observations_June2011.xls").

The temperature monitoring stations utilized 12-bit Temperature Smart Sensors and 4-channel Micro Station dataloggers from Onset (fig. 4A). These were buried in an insulated weatherproof case at a depth of approximately $45 \mathrm{~cm}$, as were the cables, for protection from animals and the cold winter air (fig. 4B). The Temperature Smart Sensors were field-placed (because depth to permafrost was not known beforehand) at an oblique angle through a 0.5 -inch (in) polyvinyl chloride (PVC) pipe so that the temperature array would fit into a 2-in-diameter auger hole. The Smart Sensors were also secured to the PVC with Devcon Plastic Welder S-220/22045 adhesive. The water-level loggers used were Rugged Troll 200s (nonvented, 30-foot [ft] range) with direct-read cable attachments (the cable ends were buried with the Micro Station datalogger cases). The Rugged Troll 200s were placed in a 16-cm length of slotted, 2-in PVC pipe with caps sealed to each end using epoxy and silicon (fig. 4C). This length of PVC pipe functions as a well casing buried at depth and insulated by soil from wintertime air, designed this way to minimize potential freezing problems during the winter. A Level Troll 100 (nonvented, 30- $\mathrm{ft}$ range) water-level logger was fastened to the trunk of a birch tree (fig. 2A, Plot ID 26; sensor height 1.7 $\mathrm{m}$ above ground surface) in order to measure air temperature and barometric pressure, the latter needed to convert the Rugged Troll 200 measurements to units of pressure relative to atmosphere. All waterlevel loggers also had a built-in temperature sensor. 


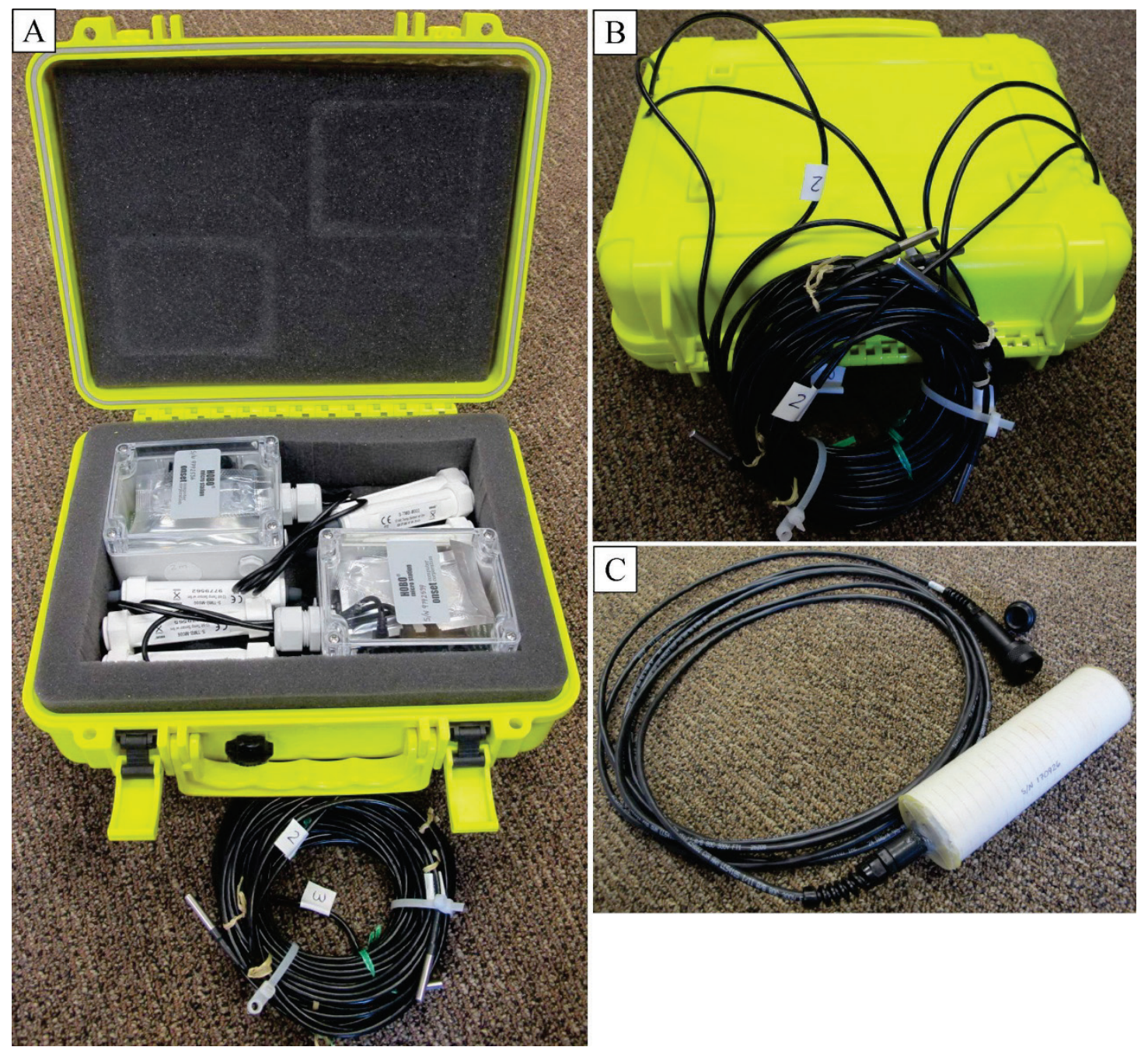

Figure 4. Instruments used to record subsurface temperature and water pressure. $(A, B)$ Two Onset 4-channel Micro Station dataloggers (3 of 4 channels used) in weatherproof case with Onset 12-bit Temperature Smart Sensors and $(C)$ Rugged Troll 200 (non-vented) water level logger with direct-read cable attachment placed inside a sealed, slotted polyvinyl chloride (PVC) pipe.

Temperature sensors at the upper spruce site were buried at depths of $0.7,17.4,34.3,50.7,67.5$, and $83.7 \mathrm{~cm}$, relative to top of mineral soil. Top of permafrost was observed at a depth of $84 \mathrm{~cm}$ during sensor installation, $0.3 \mathrm{~cm}$ below lowest temperature sensor. The water-level logger at the upper spruce site was buried at a depth of $73 \mathrm{~cm}$ in order to provide clearance above the permafrost table and thus minimize chances of the sensor freezing into the permafrost and becoming damaged. Temperature sensors at the lower deciduous site were buried at depths of 5.7, 38.3, 72.3,105.0,138.5, and $171.7 \mathrm{~cm}$, relative to top of organic soil (note: data from depths 105.0, 138.5, and $171.7 \mathrm{~cm}$ could not be downloaded due to technical difficulties). Top of permafrost at the lower deciduous site was found at a depth of $162 \mathrm{~cm}$ during sensor installation. The water-level logger at this site was buried at a depth of $148 \mathrm{~cm}, 14 \mathrm{~cm}$ above the permafrost table. 


\section{June 2011}

Measurements collected during the June 18-24, 2011 fieldwork included depths to ground ice and the water table, soil texture and moisture, water body elevations (using GPS [global positioning system] in conjunction with LIDAR [light detection and ranging] elevation), and soil temperatures at various locations within soil profiles using a hand probe (Fluke 52II Thermometer with Type T thermocouple and 6-in [15.2-cm] stainless steel probe). Site locations are plotted in figure $2 B$.

Measurements were generally made from soil pits and auger holes. Soil pits were dug using a spade shovel to a maximum depth of about $1 \mathrm{~m}$; deeper inspection was carried out by boring downward through the bottom of the soil pit using a manual, 3-in $(7.6-\mathrm{cm})$ bucket auger with five 1-m-long extensions until being rejected by ground ice or gravel or until exceeding available time (about 2 hours per pit). Representative soil samples were collected using a 2 - by 4 -in $(5.1$ - by $10.2-\mathrm{cm})$ soil core sampler with plastic liners. The soil samples were returned to the laboratory for measurements of soil moisture using the gravimetric method and of grain-size distribution using sieves and shaker table.

\section{August 2011}

During fieldwork taking place August 19-27, 2011, the sites visited during June 2011 were reexamined to observe seasonal changes in ground ice, soil moisture, and water-table elevation. In addition, the data from the temperature monitoring stations and water-level loggers were downloaded. Ground temperatures were also measured at select locations using the hand probe to confirm interpretations about the presence or absence of frozen conditions. Soil observations were made using the 3-in $(7.6-\mathrm{cm})$ auger without first digging a pit, as was done in June, so that more measurements of permafrost distribution and water-table elevation could be taken. The site locations are plotted in figure 5 . 

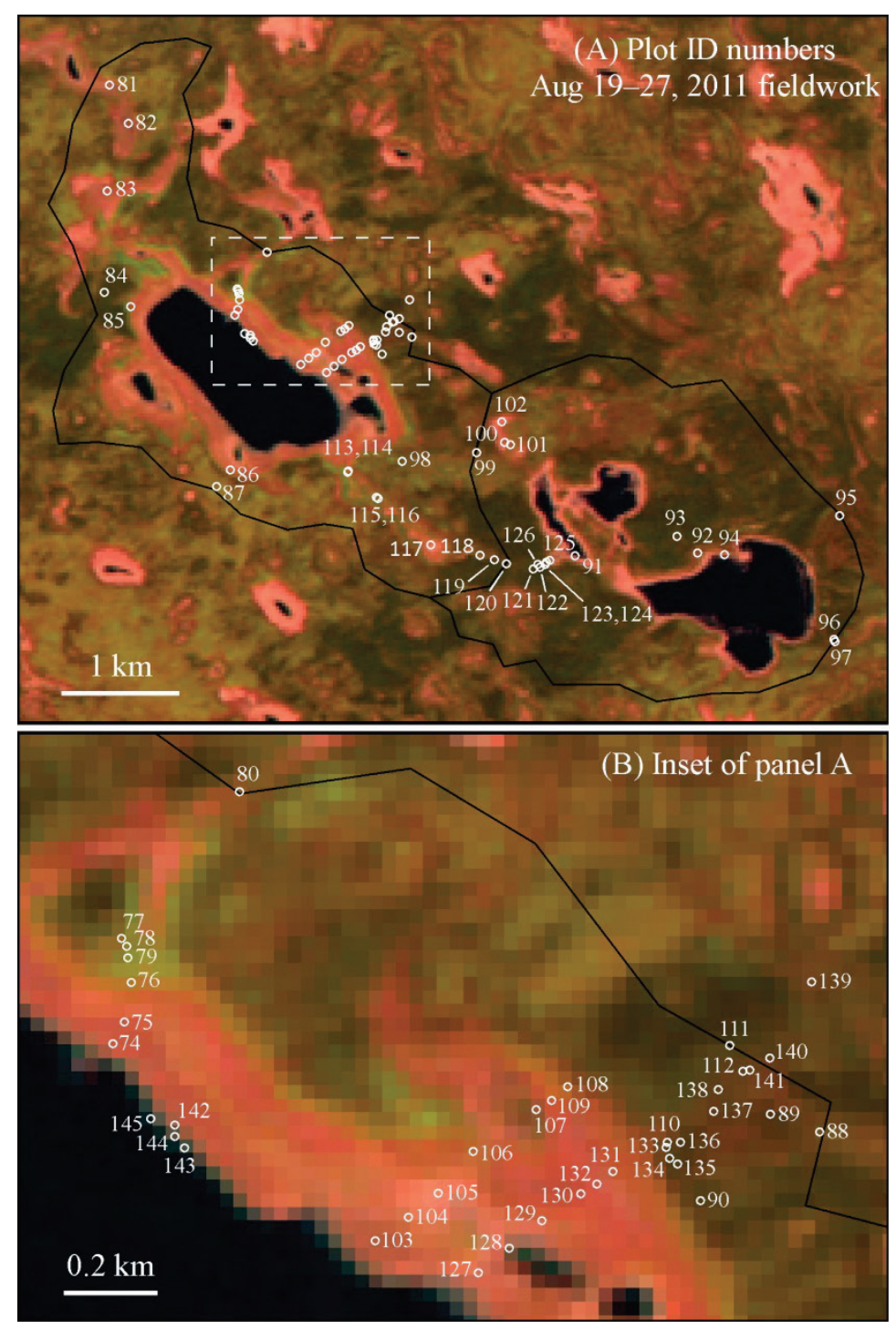

Figure 5. Site locations and plot identification (ID) numbers for the fieldwork period August 19-27, 2011. Plot ID numbers are referenced in the data files. They are different from "site names," also referenced in the data files. (Base image taken by Landsat 5, May 28, 2011.)

\section{Thermal and Hydrological Observations}

\section{Soil Texture and Moisture}

Based on sieving in the laboratory (table 2) and hand texturing in the field (data file "Soil_logs_June2011.xls"), the sediment overlying fluvial gravel consists primarily of fine sand and silt with minor clay ( $\leq 9$ percent by volume at 16 out of 17 sites). Observed depths to gravel in the Twelvemile Lake watershed were found to be greatest in areas near the present lake margin and in the upland spruce forest $(>2 \mathrm{~m})$ and lowest in the inlet and outlet channels near the watershed boundary $(0.1-0.3 \mathrm{~m})$ (data files “Observations_June2011.xls" and “Observations_Aug2011.xls").

Measured soil moisture, as a volumetric fraction, ranges from 0.04 to 0.74 (data files "Soil_moisture_June2011.xls" and "Soil_moisture_Aug2011.xls"). The highest soil moistures were 
generally observed in organic soils of low-lying areas, while the lowest soil moistures tended to occur in silts and sands overlying permafrost in the upland spruce forest. Soil moisture observed during August 2011, averaged over the soil column at each site, correlates strongly (coefficient of determination $\left(\mathrm{R}^{2}\right)=$ 0.79 ) to observed depth to permafrost (fig. 6), with a regression exponent $(-0.53)$ close to the theoretical value $(-0.5)$ based on the approximation to the Stefan equation in Shur and others (2005).

Table 2. Laboratory-measured, grain-size mass fractions of soil samples collected from Twelvemile Lake and Buddy Lake watersheds, Alaska, during the June 18-24, 2011 fieldwork. Mesh sizes range from less than 0.063 millimeters to more than 2 millimeters. See figure $2 B$ for plot identification (ID) locations.

[mm, millimeter; $\mathrm{m}$, meter; $\mathrm{g} \mathrm{g}^{-1}$, gram gram $^{-1}$; $\mathrm{cm}$, centimeter; $\sim$, approximately; $>$, greater than; <, less than]

\begin{tabular}{|c|c|c|c|c|c|c|c|c|}
\hline \multirow[t]{2}{*}{ Plot ID } & \multirow{2}{*}{$\begin{array}{l}\text { Depth } \\
\text { (m) }\end{array}$} & \multicolumn{6}{|c|}{ Mass fractions $\left(\mathrm{g} \mathrm{g}^{-1}\right)$ in the following mesh sizes $(\mathrm{mm})$} & \multirow[t]{2}{*}{ Comments } \\
\hline & & $>2$ & $0.5-2$ & $0.25-0.5$ & $0.125-0.25$ & $0.063-0.125$ & $<0.063$ & \\
\hline 29 & 0.47 & 0.00 & 0.00 & 0.02 & 0.28 & 0.38 & 0.31 & \\
\hline 29 & 1.63 & 0.00 & 0.00 & 0.04 & 0.77 & 0.18 & 0.02 & \\
\hline 30 & 0.51 & 0.00 & 0.00 & 0.02 & 0.11 & 0.19 & 0.68 & \\
\hline 30 & 2.82 & 0.00 & 0.00 & 0.01 & 0.16 & 0.27 & 0.55 & \\
\hline 32 & 0.28 & 0.00 & 0.00 & 0.02 & 0.33 & 0.42 & 0.24 & \\
\hline 32 & 0.78 & 0.00 & 0.00 & 0.00 & 0.04 & 0.12 & 0.84 & \\
\hline 33 & 0.43 & 0.00 & 0.00 & 0.02 & 0.12 & 0.15 & 0.71 & \\
\hline 33 & 1.41 & 0.00 & 0.00 & 0.00 & 0.02 & 0.12 & 0.86 & \\
\hline 34 & 0.35 & 0.00 & 0.01 & 0.01 & 0.26 & 0.36 & 0.37 & \\
\hline 39 & 0.23 & 0.00 & 0.01 & 0.02 & 0.11 & 0.23 & 0.62 & $\begin{array}{l}\text { Many particles of size } 0.125-0.5 \mathrm{~mm} \text { are } \\
\text { uncrushed silt }\end{array}$ \\
\hline 46 & 0.63 & 0.00 & 0.00 & 0.01 & 0.03 & 0.14 & 0.82 & Rich in organics (pine needles and roots) \\
\hline 46 & 2.95 & 0.24 & 0.01 & 0.03 & 0.19 & 0.27 & 0.26 & Gravel up to $2 \mathrm{~cm}-$ average size $\sim 0.8 \mathrm{~cm}$ \\
\hline 48 & 0.53 & 0.00 & 0.00 & 0.01 & 0.04 & 0.13 & 0.81 & \\
\hline 48 & 1.81 & 0.00 & 0.00 & 0.01 & 0.25 & 0.27 & 0.47 & \\
\hline 57 & 0.25 & 0.00 & 0.00 & 0.00 & 0.02 & 0.26 & 0.71 & \\
\hline 57 & 0.69 & 0.00 & 0.00 & 0.00 & 0.04 & 0.24 & 0.72 & \\
\hline 68 & 0.76 & 0.00 & 0.00 & 0.00 & 0.01 & 0.20 & 0.78 & \\
\hline 68 & 0.86 & 0.00 & 0.00 & 0.00 & 0.12 & 0.28 & 0.60 & \\
\hline 69 & 0.43 & 0.00 & 0.00 & 0.00 & 0.06 & 0.16 & 0.77 & \\
\hline 69 & 1.14 & 0.00 & 0.00 & 0.01 & 0.25 & 0.62 & 0.12 & \\
\hline 41 & 0.46 & 0.01 & 0.05 & 0.30 & 0.49 & 0.10 & 0.04 & $\sim 50 \%$ organic by volume in $>0.5 \mathrm{~mm}$ mesh \\
\hline 41 & 0.87 & 0.00 & 0.01 & 0.12 & 0.59 & 0.18 & 0.10 & $>\sim 85 \%$ organic by volume in $>0.5 \mathrm{~mm}$ mesh \\
\hline
\end{tabular}




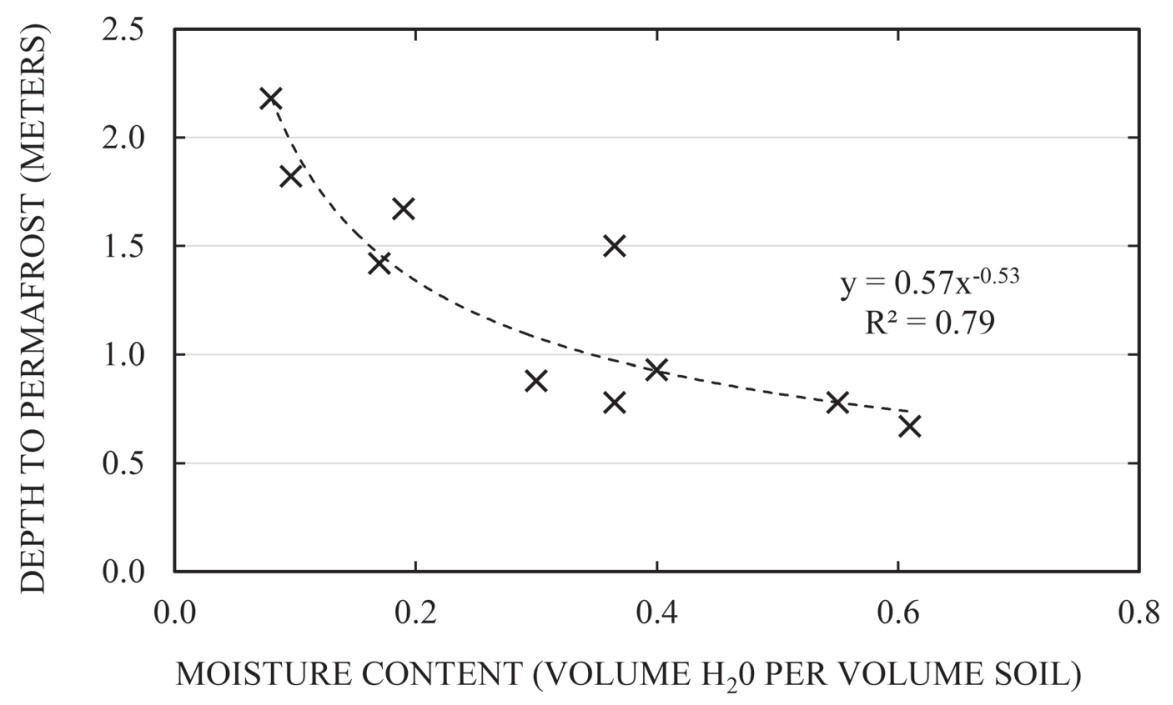

Figure 6. Depth to permafrost as a function of liquid water content at sites where both soil moisture was measured and digging was rejected by ice, August 19-27, 2011. Liquid water content is averaged over the suprapermafrost soil-profile at each site. ( $R^{2}$, coefficient of determination; $x$, moisture content; $y$, depth to permafrost)

\section{Depth to Permafrost}

Observed depths to permafrost during September 2010 and August 2011 ranged from about 0.4 to $2.7 \mathrm{~m}$ and averaged $1.2 \mathrm{~m}$ (table 1, fig. 7, data file "Observations_Aug2011.xls"). Depths to permafrost were generally lowest in the upland spruce forest and in areas where the ground is highest in electrical resistivity (fig. 7). 

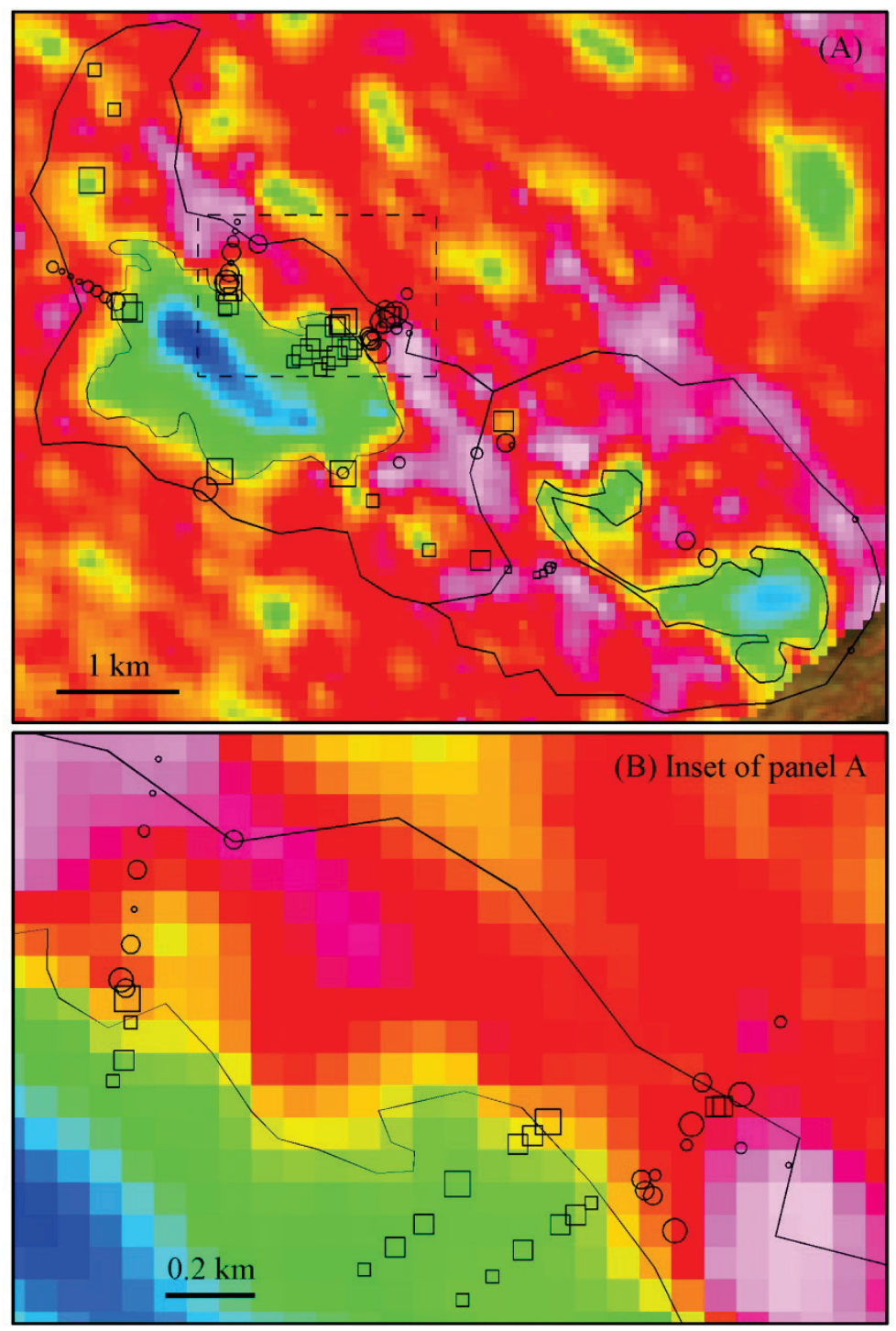

EXPLANATION

$\log _{10}$ (Resistivity)

(ohm $\cdot$ meters)

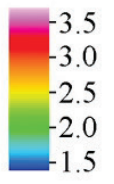

No ice (maximum depth

of observation, meters)

- $\quad 0.4-1.1$

ㅁ $1.1-2.3$

$2.3-3.2$

3.2-5.0

Ice (depth at rejection

by ice, meters)

- $0.4-0.8$

○ $0.8-1.3$

O $1.3-1.8$

1.8-2.7

Figure 7. Maximum observation depths in areas of ground ice (estimated depth to permafrost) and no ground ice, Twelvemile and Buddy Lake watersheds, Alaska, during September 2010 and August 2011. Values are superposed over the observed electrical resistivity of the upper 10 meters of ground (Minsley and others, 2012). The shallowest permafrost occurs in areas of high resistivity. Observation depths at locations without ground ice were generally limited by the presence of gravel or liquefied conditions near surface water.

During August 2011, rejection of digging by ground ice was not encountered at two spruceforested sites in the eastern Twelvemile Lake watershed (figs. 5B and 7, Plot IDs 112 and 141), even though subzero ground temperatures were observed at the maximum depths of observation (data file "Miscell_GrndTemperature_Aug2011.xls"). The material at the bottom of the auger holes was a loose gravel, and at one of the two sites the ground temperature was found to increase with depth (Plot ID 112, data file "Miscell_GrndTemperature_Aug2011.xls"), which suggests that the frozen ground was either part of seasonal frost or a thin, dry layer of permafrost (thickness of approximately $2 \mathrm{~m}$ based on an extrapolation of the measured temperature gradient). This observation prompted interest in the 
possibility of lateral groundwater flow through this area of presumably high hydraulic conductivity. Attempts were made to search for indicators of lateral groundwater flow at these sites by boring down and measuring the water-table elevation relative to that of Twelvemile Lake, but they were unsuccessful because of difficulties in digging through gravel.

\section{Depth to Water Table}

Water-table depths were measured during August 2011 at locations within the 1984 Twelvemile Lake boundary (fig. $1 B$ ), along the outlet channel of Twelvemile Lake (fig. $1 A$ ), along the inlet channel between Buddy and Twelvemile Lakes (fig. 1A), and at the east side of Buddy Lake. These depths were subtracted from LIDAR surface elevations to determine water-table elevations. Along three transects within the 1984 lake boundary (fig. 5B, Plot IDs 74-79, 103-109, and 127-132), the water-table elevation ranged from 126.4 to $126.6 \mathrm{~m}$ and averaged $126.4 \mathrm{~m}$ (excluding two outliers at Plot IDs 74 and 129) (data file "Observations_Aug2011.xls"). At the southwest side of Twelvemile Lake (fig. 5A, Plot ID 86), the water-table elevation was found to be $126.7 \mathrm{~m}$. In comparison, the lake elevation was approximately $126.4( \pm 0.2) \mathrm{m}$, as determined by spatial extrapolation of ground slope from the lake margin present during the time of LIDAR acquisition (July-September 2009). Considering uncertainty in the LIDAR $( \pm 0.1 \mathrm{~m})$ and extrapolated lake elevation $( \pm 0.2 \mathrm{~m})$, variations in water-table elevation within the 1984 lake boundary are considered too small to be detected using the methods of this study. However, spatial variation in water-table elevation was detected in the inlet and outlet channels of Twelvemile Lake. The observed water table was found to slope down towards Twelvemile Lake in both of these channels (fig. 8) (data file "Observations_Aug2011.xls"). An abrupt change in water-table elevation was observed in the inlet channel near the boundary between the Twelvemile Lake and Buddy Lake watersheds (fig. 8A). This abrupt change in elevation of the water table suggests that groundwater flow from Buddy Lake to Twelvemile Lake along the inlet channel is being restricted. Possible reasons for the flow restriction include blocking by ground ice and discontinuity of the gravel aquifer.

(A) Inlet channel

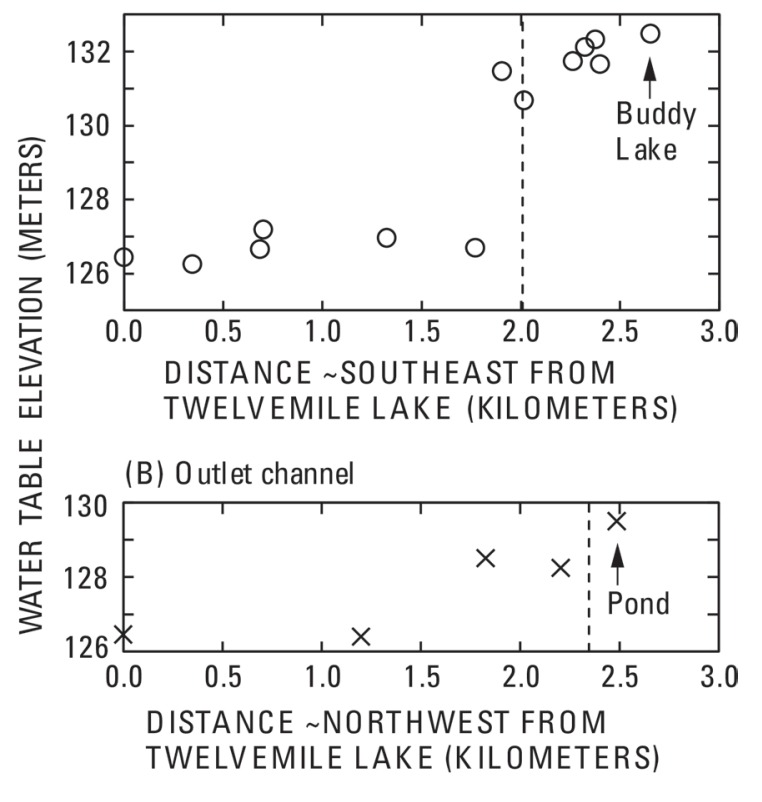

Figure 8. Water-table elevations observed in the $(A)$ inlet and $(B)$ outlet channels of Twelvemile Lake, as a function of distance from the 2010 lake boundary. The water table slopes down towards the lake in both channels. See figure $1 B$ for location of pond. ( , approximately) 
Water tables were observed both above and below frozen ground during August 2011. Water tables above frozen ground were observed in spruce forest at Plot ID 88 (fig. 5B), where it was perched approximately $7 \mathrm{~m}$ above Twelvemile Lake, and in spruce forest at Plot ID 95 (fig. $5 B$ ), where it was perched approximately $3 \mathrm{~m}$ above Buddy Lake (data file "Observations_Aug2011.xls"). A water table was also found below a 0.21 -m-thick layer of frozen soil in the inlet channel of Twelvemile Lake (fig. 5A, Plot ID 118; data file “Observations_Aug2011.xls”).

\section{Soil and Air Temperature}

Time series of daily mean ground and air temperatures observed at the upper spruce site (fig. 2A, Plot ID 22) and lower deciduous site (fig. 2A, Plot IDs 24-26) are shown in figure 9 (data files "GrndTmptr_lower_Sep2010-Aug2011.csv," "GrndTmptr_upper1of2_Sep2010-Aug2011.csv," “GrndTmptr_upper2of2_Sep2010-Aug2011.csv," and "Barometer_Sep2010-Aug2011.csv"). The values in figure 9 averaged over time periods of Oct 01-Apr 30 (approximate period of snowfall), May 01Aug 19 (approximately 70 percent of May-September thaw season), and Oct 01-Aug 19 (88\% of a full year) are listed in Table 3, including air temperatures observed at nearby Fort Yukon for comparison. 

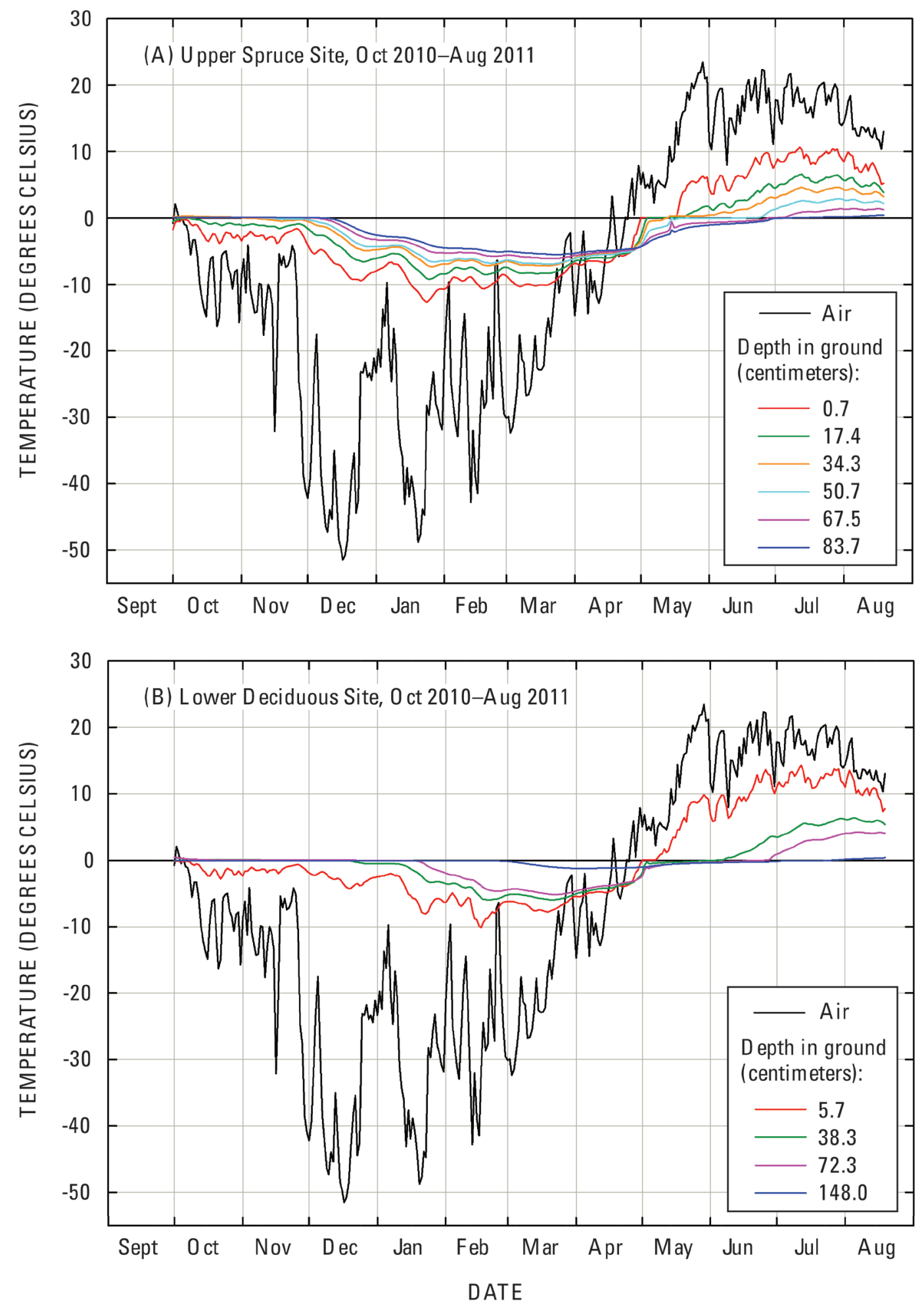

Figure 9. Ground and air temperatures observed near Twelvemile Lake at (A) the upper spruce site (Plot ID 22) and $(B)$ the lower deciduous site (Plot IDs 24-26). Air temperature shown in both $9 A$ and $9 B$ was recorded by the barometer at the lower deciduous site (Plot ID 26). Site locations are plotted in figure $2 A$. 
Table 3. Seasonal averages in observed ground temperature at the upper spruce site (Plot ID 22), lower deciduous site (Plot IDs 24, 25), and barometer (Plot ID 26) near Twelvemile Lake between October 01, 2010, and August 19, 2011. Air temperatures observed at Fort Yukon (SNOTEL \#961, Natural Resources Conservation Service) are included for comparison.

$\left[{ }^{\circ} \mathrm{C}\right.$, degrees Celsius; cm, centimeter $]$

\begin{tabular}{cccc}
\hline & \multicolumn{4}{c}{ Seasonal temperature averages $\left({ }^{\circ} \mathrm{C}\right)$} \\
& Oct $01-A p r ~ 30$ & May 01-Aug 19 & Oct 01-Aug 19 \\
\hline & \multicolumn{4}{c}{ Air, Twelvemile Lake and Fort Yukon } \\
\hline Twelvemile Lake & -19.4 & 15.1 & -7.6 \\
Fort Yukon & -18.6 & 13.6 & -7.5 \\
\hline Depth $(\mathrm{cm})$ & \multicolumn{1}{c}{ Ground, upper spruce site, Twelvemile Lake } \\
\hline 0.7 & -6.6 & 6.3 & -2.1 \\
17.4 & -4.9 & 3.3 & -2.1 \\
34.3 & -3.9 & 2.1 & -1.8 \\
50.7 & -3.7 & 0.9 & -2.1 \\
67.5 & -3.1 & -0.2 & -2.1 \\
83.7 & -2.7 & -0.8 & -2.0 \\
\hline Depth $(\mathrm{cm})$ & Ground, lower deciduous site, Twelvemile Lake \\
\hline 5.7 & -4.0 & 9.1 & 0.5 \\
38.3 & -2.2 & 2.7 & -0.5 \\
72.3 & -1.7 & 1.2 & -0.7 \\
148.0 & -0.3 & -0.2 & -0.3 \\
\hline
\end{tabular}

Average air temperatures at Twelvemile Lake and Fort Yukon for the period October 01 to August 19 are within $0.1^{\circ} \mathrm{C}$ of one another (table 3). Two differences are noted between ground temperatures observed at the upper spruce and lower deciduous sites: (a) ground surface temperatures at the upper site are about $2-3^{\circ} \mathrm{C}$ colder than at the lower site, possibly in relation to site differences in insulating moss cover and wintertime forest canopy; and (b) the active layer at the lower site is near $0^{\circ} \mathrm{C}$ ("zero curtain" period) for a longer duration than the upper site. The ground surface temperature at both sites was maintained at $0^{\circ} \mathrm{C}$ during the first 1-2 weeks of May 2011 (fig. 9). This isothermal period is likely associated with the infiltration of snowmelt down into the underlying soil column.

Miscellaneous ground temperatures measured during August 2011 are provided in data file "Miscell_GrndTemperature_Aug2011.xls." These measurements support the interpreted absence of permafrost at the following locations within the 1984 Twelvemile Lake boundary: the transect formed by Plot IDs 74-79 on the northeast side of the lake (fig. 5B) and Plot ID 86 on the southwest side of the lake (fig. 5A). The ground temperatures observed at Plot ID 112 (fig. 5B) appeared to increase with depth below about $2.4 \mathrm{~m}$, where the ground was dry and gravelly, suggesting dry or absent permafrost.

\section{Water Pressure Data}

Water pressures relative to barometric ( $\mathrm{cm} \mathrm{H}_{2} \mathrm{O}$ [water]) recorded near the permafrost table, resampled into 100 evenly spaced time bins for plotting purposes (approximately 3.25 days each), are shown in figure 10. The unprocessed data from the barometer and the water level loggers at the upper spruce site and lower deciduous site are contained in data files "Barometer_Sep2010-Aug2011.csv," "WtrLogger_upper_Sep2010-Aug2011.csv," and "WtrLogger_lower_Sep2010-Aug2011.csv," respectively. 

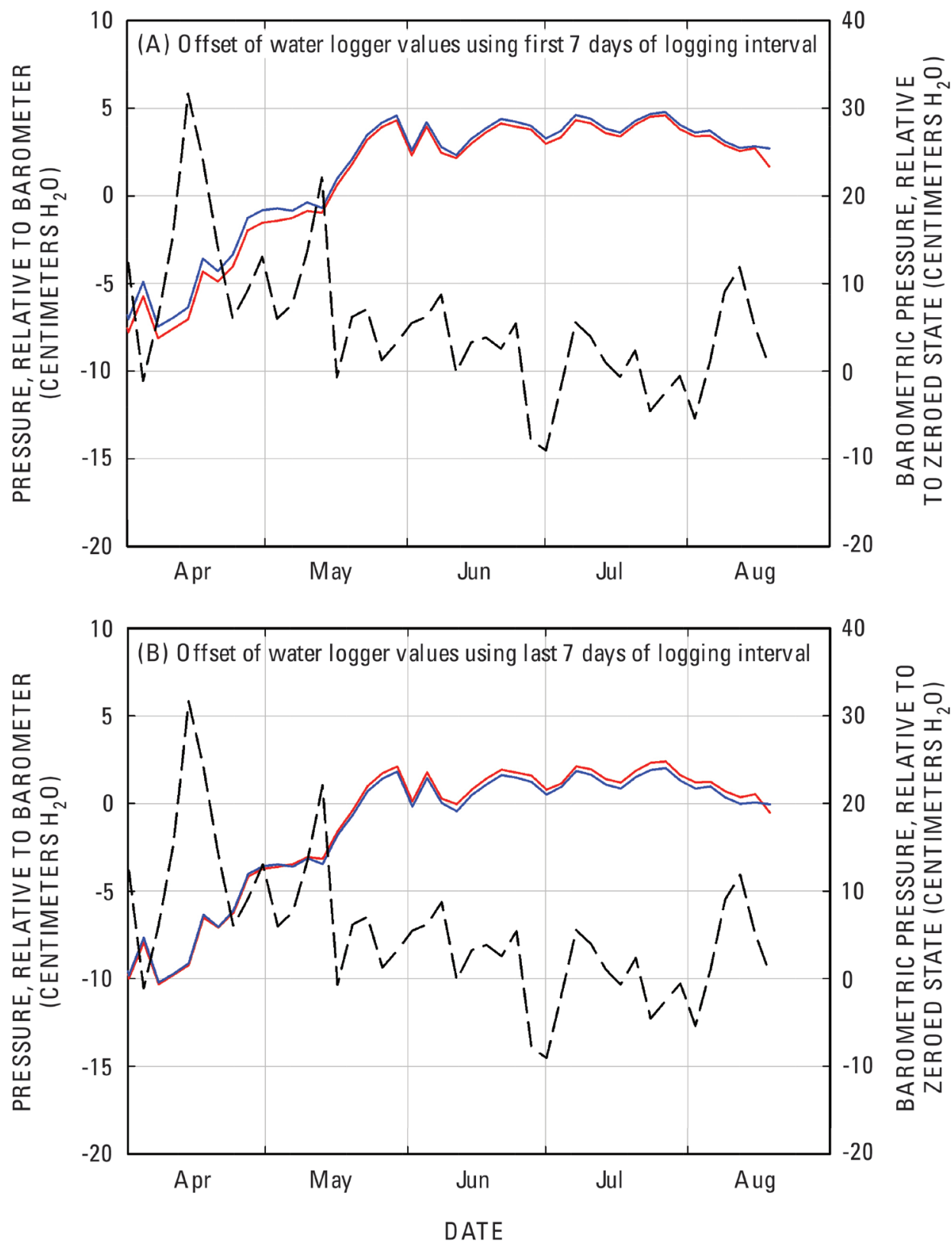

EXPLANATION

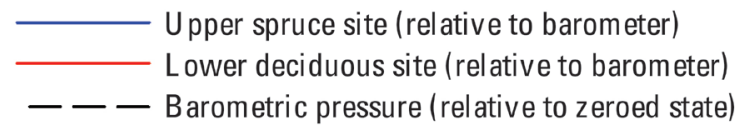

Figure 10. Water pressures observed 11 centimeters above the permafrost table at the upper spruce site (Plot ID 23) and 14 centimeters above the permafrost table at the lower deciduous site (Plot ID 25) during April-August 2011. Site locations are plotted in figure $2 A$. Water-level logger pressures (blue and red curves) are relative to barometer values (dashed curve), and barometer values are relative to an (arbitrary) zeroed state. Numerical offsets were applied to force the water-level logger values to match the barometer values during periods when the ground was known to be unsaturated. These periods were $(A)$ the first 7 days of the logging interval, and $(B)$ the last 7 days of the logging interval. $\left(\mathrm{H}_{2} \mathrm{O}\right.$, water) 
The barometer was zeroed in Fairbanks, Alaska, on September 22, 2010. The barometric pressure values in figure 10 are relative to this zeroed state; absolute pressure values are approximately $1,010 \mathrm{~cm} \mathrm{H}_{2} \mathrm{O}$ greater than the relative values. "Pressure, relative to barometer" in figure 10 was determined by subtracting the barometer value from the water-level logger value, then adding a constant, numerical offset computed such that the water-level logger and barometer values match one another during time periods when the ground was known to be unsaturated. These time intervals were chosen to be 7-day periods at the start (fig. 10A) and end (fig. 10B) of the logging periods, when the soil was observed to be unsaturated and surrounding temperatures were in the operational range $\left(0-50^{\circ} \mathrm{C}\right)$.

Observations from auger holes at both water-level logger sites on August 20, 2011, revealed unsaturated conditions down to, and below, the depths of the water-level loggers. Therefore, the late August water pressures in figure 10 (red and blue curves) correspond to unsaturated ground conditions. During the preceding 3-month period (mid-May to mid-August), the recorded pressures underwent fluctuations on the order of $1 \mathrm{~cm} \mathrm{H}_{2} \mathrm{O}$ (fig. 10). These fluctuations are about equal to the accuracy of the water-level loggers $(0.9 \mathrm{~cm})$ and are an order of magnitude lower than fluctuations in barometric pressure (fig. 10, dashed-black curve). These small pressure fluctuations recorded by the water-level loggers during the 2011 thaw season are interpreted to indicate an absence of saturated conditions, within the limits of our detection.

\section{Acknowledgments}

Support for this study was provided by the U.S. Geological Survey (USGS) Mendenhall Research Fellowship Program and the USGS National Research Program. Technical assistance was provided by the following individuals: J. Abraham, M.T. Jorgenson, J. O'Donnell, B. Minsley, J. Rover, and B. Smith. The LIDAR data were acquired as a part of the USGS Yukon River Basin project supported by the Climate Effects Network.

\section{References Cited}

Abraham, Jared, 2011, A promising tool for subsurface permafrost mapping-An application of airborne geophysics from the Yukon River Basin, Alaska: U. S. Geological Survey Fact Sheet 20113133, 4 p.

Ball, L.B., Smith, B.D., Minsley, B.J., Abraham, J.D., Voss, C.I., Astley, B.N., Deszcz-Pan, Maryla, and Cannia, J.C., 2011, Airborne electromagnetic and magnetic geophysical survey data of the Yukon Flats and Fort Wainwright areas, central Alaska, June 2010: U.S. Geological Survey Open-File Report 2011-1304, 28 p.

Chapin, F.S., III, Viereck, L.A., Adams, P.C., Van Cleve, Keith, Fastie, C.L., Ott, R.A., Mann, Daniel, and Johnstone, J.F., 2006, Successional processes in the Alaskan boreal forest, in Chapin, F.S., III, Oswood, M.W., Van Cleve, Keith, Viereck, L.A., and Verbyla, D.L., eds., Alaska's changing boreal forest: New York, Oxford University Press, p. 100-132.

Gesch, D.B., 2007, The National Elevation Dataset, in Maune, D.F., ed., Digital elevation model technologies and applications - The DEM users manual ( $2 \mathrm{~d}$ ed.): Bethesda, Md., American Society for Photogrammetry and Remote Sensing, p. 99-118.

Minsley, B.J, Abraham, J.D., Smith, B.D., Cannia, J.C., Voss, C.I., Jorgenson, M.T., Walvoord, M.A., Wylie, B.K., Anderson, Lesleigh, Ball, L.B., Deszcz-Pan, Maryla, Wellman, T.P., and Ager, T.A., 2012, Airborne electromagnetic imaging of discontinuous permafrost: Geophysical Research Letters, 39, L02503, doi:10.1029/2011GL050079. 
Nakanishi, A.S., and Dorava, J.M., 1994, Overview of environmental and hydrogeologic conditions at Fort Yukon, Alaska: U.S. Geological Survey Open-File Report 94-526, 133 p.

Shur, Yuri, Hinkel, K.M., and Nelson, F.E., 2005, The transient layer-Implications for geocryology and climate-change science: Permafrost and Periglacial Processes, 16, no. 1, p. 5-17.

Williams, J.R., 1962, Geologic reconnaissance of the Yukon Flats district, Alaska: [U.S.] Geological Survey Bulletin 1111-H, 43 p. 


\section{Appendix 1: Description of Data Files}

Each section below describes a data file that accompanies this report. The section titles give the names of the data files, and tables explain the contents of each data file column. The files can be found in the Downloads folder of the report Web page, or they can be opened directly by clicking on the links in each section. Each Microsoft Excel file (*.xls) is also provided in comma-delimited format (*.csv) or PDF format (*.pdf) in the Downloads folder on the report Web page.

(Abbreviations used in this section: $\mathrm{mm} / \mathrm{dd} / \mathrm{yyyy}$, month/day/year; hh:mm, hour:minute; GMT, Greenwich mean time; kPa, kilopascal; deg, degree; cm, centimeter; m, meter; ID, identification; GPS, global positioning system; LIDAR, light detection and ranging; $\mathrm{cm}^{3}$, cubic centimeter; $\mathrm{g}$, gram; $\mathrm{g} \mathrm{cm}^{-3}$, gram per cubic centimeter)

\section{Data File: Barometer_Sep2010-Aug2011.csv}

Barometric pressure and air temperature measurements near the lower deciduous site (Plot ID 26), September 2010 to August 2011.

\begin{tabular}{ll}
\hline \multicolumn{1}{c}{ Column Header } & \multicolumn{1}{c}{ Description } \\
\hline Date and Time & Date and time, in month, day, year, hour, minutes $(\mathrm{mm} / \mathrm{dd} /$ yyyy hh:mm) (GMT-09:00) \\
Seconds elapsed & Number of seconds since start of logging \\
Pressure $(\mathrm{kPa})$ & Barometric pressure, in kilopascals $(\mathrm{kPa})$ relative to zeroed instrument value on September 22, 2010 \\
Temperature $(\operatorname{deg} \mathrm{C})$ & Temperature, in degrees Celsius $\left({ }^{\circ} \mathrm{C}\right)$ \\
\hline
\end{tabular}

\section{Data File: GrndTmptr_lower_Sep2010-Aug2011.csv}

Ground temperature measured at the lower deciduous site (Plot ID 24), September 2010 to August 2011. Depths are measured relative to top of organic soil.

\begin{tabular}{ll}
\hline \multicolumn{1}{c}{ Column Header } & \multicolumn{1}{c}{ Description } \\
\hline$\#$ & Sequential number of logger recording \\
Date and time (GMT-09:00) & Date and time, in month, day, year, hour, minutes (mm/dd/yyyy hh:mm) (GMT-09:00) \\
Temperature (deg C) - Ch 1 & Ground temperature, in degrees Celsius $\left({ }^{\circ} \mathrm{C}\right)$, depth 5.7 centimeters $(\mathrm{cm})$ \\
Temperature (deg C) - Ch 2 & Ground temperature $\left({ }^{\circ} \mathrm{C}\right)$, depth $38.3 \mathrm{~cm}$ \\
Temperature (deg C) - Ch 3 & Ground temperature $\left({ }^{\circ} \mathrm{C}\right)$, depth $72.3 \mathrm{~cm}$ \\
\hline
\end{tabular}

\section{Data File: GrndTmptr_upper1of2_Sep2010-Aug2011.csv}

Ground temperature measured at the upper spruce site (Plot ID 22), upper three sensors, September 2010 to August 2011. Depths are measured relative to top of mineral soil.

\begin{tabular}{ll}
\hline \multicolumn{1}{c}{ Column Header } & \multicolumn{1}{c}{ Description } \\
\hline$\#$ & Sequential number of logger recording \\
Date and time (GMT-09:00) & Date and time, in month, day, year, hour, minutes (mm/dd/yyyy hh:mm) (GMT-09:00) \\
Temperature (deg C) - Ch 1 & Ground temperature, in degrees Celsius $\left({ }^{\circ} \mathrm{C}\right)$, depth 0.7 centimeters $(\mathrm{cm})$ \\
Temperature (deg C) - Ch 2 & Ground temperature $\left({ }^{\circ} \mathrm{C}\right)$, depth $17.4 \mathrm{~cm}$ \\
Temperature (deg C) - Ch 3 & Ground temperature $\left({ }^{\circ} \mathrm{C}\right)$, depth $34.3 \mathrm{~cm}$ \\
\hline
\end{tabular}

\section{Data File: GrndTmptr_upper2of2_Sep2010-Aug2011.csv}

Ground temperature measured at the upper spruce site (Plot ID 22), lower three sensors, September 2010 to August 2011. Depths are measured relative to top of mineral soil. 


\begin{tabular}{ll}
\hline \multicolumn{1}{c}{ Column Header } & \multicolumn{1}{c}{ Description } \\
\hline$\#$ & Sequential number of logger recording \\
Date and time (GMT-09:00) & Date and time, in month, day, year, hour, minutes (mm/dd/yyyy hh:mm) (GMT-09:00) \\
Temperature (deg C) - Ch 1 & Ground temperature, in degrees Celsius $\left({ }^{\circ} \mathrm{C}\right)$, depth 50.7 centimeters $(\mathrm{cm})$ \\
Temperature (deg C) - Ch 2 & Ground temperature $\left({ }^{\circ} \mathrm{C}\right)$, depth $67.5 \mathrm{~cm}$ \\
Temperature (deg C) - Ch 3 & Ground temperature $\left({ }^{\circ} \mathrm{C}\right)$, depth $83.7 \mathrm{~cm}$ \\
\hline
\end{tabular}

\section{Data File: Miscell_GrndTemperature_Aug2011.xls}

Miscellaneous ground temperatures measured in the Twelvemile Lake watershed using a hand probe (Fluke 52II Thermometer with Type T thermocouple and 6-in [15.2-cm] stainless steel probe) during the fieldwork period of August 19-27, 2011. These measurements supplement interpretations about the presence or absence of frozen ground conditions.

\begin{tabular}{ll}
\hline \multicolumn{1}{c}{ Column Header } & \multicolumn{1}{c}{ Description } \\
\hline Plot ID & Identification used on map figures showing site locations \\
Site name & "Site name" in file "Observations_Aug2011.xls" \\
Date & Date of measurement, in month, day, year (mm/dd/yyyy) \\
Description & Brief description of site \\
Depth & $\begin{array}{l}\text { Depth of ground temperature relative to top of organic soil (or mineral soil if no organic soil), in } \\
\text { meters (m) }\end{array}$ \\
Ground temperature & Value of ground temperature, in degrees Celsius $\left({ }^{\circ} \mathrm{C}\right)$ \\
Comment & Comment \\
\hline
\end{tabular}

\section{Data File: Observations_Aug2011.xls}

General description of sites visited near Twelvemile Lake and Buddy Lake during the fieldwork period of August 19-27, 2011. All depths are relative to top of organic soil unless noted otherwise.

\begin{tabular}{ll}
\hline \multicolumn{1}{c}{ Column Header } & \multicolumn{1}{c}{ Description } \\
\hline Plot ID & Identification used on map figures showing site locations \\
Longitude & Global positioning system (GPS) longitude of site (decimal degrees, datum: WGS1984) \\
Latitude & GPS latitude of site (decimal degrees, datum: WGS1984) \\
Site name & Field names given to sites; those revisited after June 2011 fieldwork are appended with \\
& “-b” \\
Observation type & $\begin{array}{l}\text { Method used to make observation: auger, hand auger; pit, soil pit dug with shovel; } \\
\text { surface, surface observation involving no digging }\end{array}$ \\
Ground surface elevation & Elevation above sea level of site, in meters (m), determined using GPS coordinates and \\
& topographic map from light detection and ranging (LIDAR) \\
Top of gravel depth & Depth to top of gravel (m) \\
Water table depth & Depth to water table (m) \\
Ice rejection depth & Depth to rejection by ice (m), interpreted as depth to top of permafrost \\
Max observation depth & Maximum depth of observation (m) \\
Vegetation category & Vegetation category assigned to site (meadow, shrubland, deciduous forest, or spruce \\
& forest) \\
Organic layer thickness at surface & Total thickness of organic layer at ground surface (m), including litter and organics of \\
& fibric, hemic, and sapric materials \\
Picture numbers & Photographs taken at each site; not with report but available upon request \\
Comment & Comment \\
Date & Date of observation, in month, day, year (mm/dd/yyyy) \\
\hline
\end{tabular}




\section{Data File: Observations_June2011.xls}

General description of sites visited around Twelvemile Lake and Buddy Lake during the fieldwork period of June 18-24, 2011. All depths are relative to top of organic soil unless noted otherwise.

\begin{tabular}{ll}
\hline \multicolumn{1}{c}{ Column Header } & \multicolumn{1}{c}{ Description } \\
\hline Plot ID & Identification used on map figures showing site locations \\
Longitude & Global positioning system (GPS) longitude of site (decimal degrees, datum: WGS1984) \\
Latitude & GPS latitude of site (decimal degrees, datum: WGS1984) \\
Site name & Field names given to sites \\
Observation type & Method used to make observation: auger, hand auger; pit, soil pit dug with shovel; \\
& surface, surface observation involving no digging \\
Description & Brief site description \\
Ground surface elevation & Elevation above sea level of site, in meters (m), determined using GPS coordinates and \\
& topographic map from light detection and ranging (LIDAR) \\
Gravel depth range & Observed depth range of gravel (m); for example, 0.7-0.9, gravel found at depth 0.7 to \\
& 0.9 m; 0.9-, top of gravel observed at depth 0.9 m and bottom of gravel not found \\
Water table depth & Depth to water table (m) \\
Ice depth range & Observed depth range of ground ice (m); for example, 0.7-0.9, ice found at depth 0.7 to \\
& 0.9 m; 0.9-, top of ice observed at depth 0.9 m and bottom of ice not found \\
Max observation depth & Maximum depth of observation (m) \\
Vegetation category & Vegetation category assigned to site (meadow, shrubland, deciduous forest, or spruce \\
& forest) \\
Organic layer thickness at surface & Total thickness of organic layer at ground surface (m), including litter and organics of \\
& fibric, hemic, and sapric materials \\
Picture numbers & Photographs taken at each site; not with report but available upon request \\
Date & Date of observation, in month, day, year (mm/dd/yyyy) \\
\hline
\end{tabular}

\section{Data File: Soil_logs_June2011.xls}

Field descriptions of soil from pits and auger holes near Twelvemile Lake and Buddy Lake during the fieldwork period of June 18-24, 2011. All depths (cm) are measured relative to top of organic soil (or mineral soil if no organic soil is present). Soil horizon designations: A, zone of eluviation; C, soil parent material; L, limnic deposits; Oi, fibric organic material; Oa, sapric organic material; Oe, hemic organic material; Oae, combination of $\mathrm{Oa}$ and $\mathrm{Oe}$; $\mathrm{Ob}$, buried organic layer; subscript letter $\mathrm{f}$ denotes presence of ice; subscript number denotes numbering downward from top of soil column when multiple horizons of the same type are present (for example, the sequence $\mathrm{C}_{1}, \mathrm{C}_{2}, \mathrm{C}_{3}$ in downward direction).

\section{Data File: Soil_moisture_Aug2011.xls}

Laboratory measurements of water content and bulk density of soil samples collected near Twelvemile Lake and Buddy Lake during the fieldwork period of August 19-27, 2011. Percent water loss (by mass) was measured after baking samples at $90^{\circ} \mathrm{C}$ for 3 days. See description of data file "Soil_logs_June2011.xls" in this appendix for soil horizon abbreviations.

\begin{tabular}{ll}
\hline \multicolumn{1}{c}{ Column Header } & \multicolumn{1}{c}{ Description } \\
\hline Plot ID & Identification used on map figures showing site locations \\
Site name & Site names listed in "Site name" column of file "Observations_Aug2011.xls"; sites \\
& revisited after June 2011 fieldwork are appended with "-b" \\
Depth at top of sample & $\begin{array}{l}\text { Depth to top of soil sample, measured relative to top of organic soil (or top of mineral } \\
\text { soil if no organic soil), in meters (m) }\end{array}$
\end{tabular}


Sample orientation

Horizon (June 2011 designation)

Sample volume

(Water volume) / (sample volume)

Sample dry weight

Sample bulk density
Orientation of soil sample (vertical or horizontal)

Soil horizon based on June 2011 description of soil profile (site names with and without '-b' are co-located, for example, site 01 visited during June 2011 is co-located with site 01-b visited during August 2011

Volume of soil sample after extraction from ground, in cubic centimeters $\left(\mathrm{cm}^{3}\right)$

Fraction of (volume of water lost from sample during baking) to (volume of soil sample after extraction from ground), assuming a water density of 1 gram per cubic centimeter $\left(\mathrm{g} \mathrm{cm}^{-3}\right)$

Weight of soil sample after baking, in grams $(\mathrm{g})$

Bulk density of soil sample after baking, calculated as fraction of sample dry weight to sample volume after extraction from ground, in grams per cubic centimeter $\left(\mathrm{g} \mathrm{cm}^{-3}\right)$

\section{Data File: Soil_moisture_June2011.xls}

Laboratory measurements of water content and bulk density of soil samples collected near Twelvemile Lake and Buddy Lake during the fieldwork period of June 18-24, 2011. Percent water loss (by mass) was measured after baking samples at $90^{\circ} \mathrm{C}$ for 3 days. See description of data file "Soil_logs_June2011.xls" in this appendix for soil horizon abbreviations.

\begin{tabular}{ll}
\hline \multicolumn{1}{c}{ Column Header } & \multicolumn{1}{c}{ Description } \\
\hline Plot ID & Identification used on map figures showing site locations \\
Site name & Site names listed in "Site name" column of file "Observations_June2011.xls" \\
Sample depth & Depth to top (center) of soil sample of vertical (horizontal) orientation, measured \\
& relative to top of organic soil (or top of mineral soil if no organic soil), in meters (m) \\
Sample orientation & Orientation of soil sample (vertical or horizontal) \\
Horizon & Soil horizon based on soil profiles recorded in data file "Soil_logs_June2011.xls" \\
Sample volume & Volume of soil sample after extraction from ground, in cubic centimeters (cm ${ }^{3}$ ) \\
(Water volume) / (sample volume) & Fraction of (volume of water lost from sample during baking) to (volume of soil \\
& sample after extraction from ground), assuming a water density of 1 gram per cubic \\
& centimeter (g cm ${ }^{-3}$ ) \\
Sample dry weight & Weight of soil sample after baking, in grams (g) \\
Sample bulk density & Bulk density of soil sample after baking, calculated as fraction of sample dry weight to \\
& sample volume after extraction from ground, in grams per cubic centimeter (g cm ${ }^{-3}$ )
\end{tabular}

\section{Data File: WtrLogger_lower_Sep2010-Aug2011.csv}

Water pressure and ground temperature recorded by the water-level logger at the lower deciduous site (Plot ID 25), September 2010 to August 2011. The pressure and temperature sensors are at a depth of $148 \mathrm{~cm}$ (relative to top of organic soil), $14 \mathrm{~cm}$ above the permafrost table during September 2010 .

\begin{tabular}{ll}
\hline \multicolumn{1}{c}{ Column Header } & \multicolumn{1}{c}{ Description } \\
\hline Date and Time & $\begin{array}{l}\text { Date and time, in month, day, year, hour, minutes } \\
(\mathrm{mm} / \mathrm{dd} / \text { yyyy hh:mm) (GMT-09:00) }\end{array}$ \\
Seconds elapsed & Number of seconds since start of logging \\
Pressure $(\mathrm{kPa})$ & Absolute pressure, in kilopascals $(\mathrm{kPa})$ \\
Temperature $(\operatorname{deg} \mathrm{C})$ & Temperature, in degrees Celsius $\left({ }^{\circ} \mathrm{C}\right)$ \\
\hline
\end{tabular}

\section{Data File: WtrLogger_upper_Sep2010-Aug2011.csv}

Water pressure and ground temperature recorded by the water-level logger at the upper spruce site (Plot ID 23), September 2010 to August 2011. The pressure and temperature sensors are at a depth of $73 \mathrm{~cm}$ (relative to top of mineral soil), $11 \mathrm{~cm}$ above the permafrost table during September 2010. 


\begin{tabular}{ll}
\hline \multicolumn{1}{c}{ Column Header } & \multicolumn{1}{c}{ Description } \\
\hline Date and Time & $\begin{array}{l}\text { Date and time, in month, day, year, hour, minutes } \\
(\mathrm{mm} / \mathrm{dd} / \mathrm{yyyy} \text { hh:mm) }(\mathrm{GMT}-09: 00)\end{array}$ \\
Seconds elapsed & $\begin{array}{l}\text { Number of seconds since start of logging } \\
\text { Absolute pressure, in kilopascals }(\mathrm{kPa})\end{array}$ \\
Pressure $(\mathrm{kPa})$ & $\begin{array}{l}\text { Temperature, in degrees Celsius }\left({ }^{\circ} \mathrm{C}\right) \\
\text { Temperature }(\operatorname{deg} \mathrm{C})\end{array}$ \\
\hline
\end{tabular}

